WP 15-24

\author{
Marianna Brunetti \\ University of Rome Tor Vergata, Italy
}

Rocco Ciciretti

University of Rome Tor Vergata, Italy

The Rimini Centre for Economic Analysis, Italy

Ljubica Djordjevic

Goethe University, Germany

\title{
THE DETERMINANTS OF HOUSEHOLD'S BANK SWITCHING
}

\begin{abstract}
Copyright belongs to the author. Small sections of the text, not exceeding three paragraphs, can be used provided proper acknowledgement is given.
\end{abstract}

The Rimini Centre for Economic Analysis (RCEA) was established in March 2007. RCEA is a private, nonprofit organization dedicated to independent research in Applied and Theoretical Economics and related fields. RCEA organizes seminars and workshops, sponsors a general interest journal The Review of Economic Analysis, and organizes a biennial conference: The Rimini Conference in Economics and Finance (RCEF) . The RCEA has a Canadian branch: The Rimini Centre for Economic Analysis in Canada (RCEACanada). Scientific work contributed by the RCEA Scholars is published in the RCEA Working Papers and Professional Report series.

The views expressed in this paper are those of the authors. No responsibility for them should be attributed to the Rimini Centre for Economic Analysis. 


\title{
The Determinants of Household's Bank Switching*
}

\author{
Brunetti, M.† Ciciretti, R. $\ddagger$ Djordjevic, Lj. $\S$
}

First Draft: October 2013

This Version: June 2015

\begin{abstract}
We investigate the determinants of households' bank switching in 2006-2012 period exploiting a unique representative dataset from Bank of Italy Survey on Household Income and Wealth that follows the households and their bank(s) over time. Focusing on the features of the household-bank relationship, we find that exclusivity (using a single bank), intensity (number of services used), and scope (bank services used) of the relationship with the bank play a role in shaping the households' decision to switch. Moreover, we find that this decision is strongly and positively correlated with both taking out and paying off a mortgage. We also find that the risk preferences, mobility and economic condition of the household are not associated with its propensity to switch, whereas education and financial literacy do matter for this decision, albeit with opposite effects. Cooperative and unlisted banks are significantly less likely to be discarded. As expected, competition plays a role increasing switching.
\end{abstract}

Keywords: household-bank relationship, switching cost, bank services

\section{JEL Classification: G21; D14}

\footnotetext{
* We would like to thank Giuseppe Ilardi at Bank of Italy, who provided the regression estimates based on the restricted version of the SHIW. We are also grateful to all participants at the 2015 Regulating Consumer Credit Conference (Federal Reserve bank of Philadelphia), 2015 XVI Workshop on Quantitative Finance (Parma), 2014 RCEA Conference (Rimini), the PRIN (prot. 2010J3LZEN) Intermediate Workshop (Rome), the 2nd Macro Banking and Finance Workshop (Rome), the 2015 CSEF Seminar Cycle at University of Naples Federico II, and the 2014 Seminar Cycle at the Federal Reserve Bank of New York, the University of Siena, NHH-Bergen, and at the University of Ancona. We are also indebted to Linda Allen, Ata Bertay, Fabio Braggion, Eloisa Campioni, Nicola Cetorelli, Peter de Goeij, Leo Ferraris, Stefano Gagliarducci, Elisa Luciano, Alberto Manconi, Fabrizio Mattesini, Fabiana Penas, Franco Peracchi, Luc Renneboog, Giancarlo Spagnolo, Geoffrey Tombeur, Costanza Torricelli, and Alberto Zazzaro for helpful comments and suggestions.

$\dagger$ Department of Economics and Finance, University of Roma Tor Vergata, CEIS and CeFin Fellow. E-mail: marianna.brunetti@uniroma2.it

‡Department of Economics and Finance, University of Rome Tor Vergata, CEIS and RCEA-Rimini Fellow. E-mail: rocco.ciciretti@uniroma2.it

§ SAFE-Goethe University. E-mail: djordjevic@safe.uni-frankfurt.de
} 


\section{Introduction}

The bank clients are increasingly taking control of their banking relationships. At the world level, the proportion of clients planning to change banks was $12 \%$ in 2012 , with sensitivity to fees and charges leading the change (Ernst and Young, 2012). In response, the banks need to embrace this trend and give greater flexibility, choice and control to their customers. As Ernst and Young (2012) puts it: "Giving more power to customers may feel uncomfortable, but in the long run banks that do so will position themselves for success in the future". Basel III also draws attention to the bank relationship with its retail clients. The Bank for International Settlements (BIS) liquidity requirements discriminate between "stable" and "unstable" deposits, whereby the set criteria for being stable is that: "the depositors have other established relationships with the bank that make deposit withdrawal highly unlikely' (paragraphs 74 and 75, BIS, 2013). From both banks' and regulator's perspective it is important to understand what characteristics are associated with the 'stability' of a deposit. The banks can affect the relative stability of their deposits through their relationship with the clients and by attracting more stable clients.

Despite these trends in retail banking and policy relevance, there is little research on the dynamics of household-bank relationship over time. To the best of our knowledge, this paper represents the first attempt in the literature to investigate household's decision to switch bank, focusing in particular on the features of their relationship, such as the number and type of bank services a household uses with the bank and whether it uses other banks.

To this end, we exploit a unique panel dataset mainly drawn from the 2006-2012 Bank of Italy Survey on Household Income and Wealth, a biannual populationrepresentative survey. Italy lends itself particularly well to this analysis since on average as much as one out of four households in the sample change their main bank between two consecutive waves. Furthermore, the switching of households is especially important in countries such as Italy, in which the bulk of bank financing comes from the deposits, with less reliance on the wholesale funding (De Bonis et al., 2012). 
Our dataset identifies at each point in time the bank(s) chosen by each household and the bank services used with the main bank. In other words, we are able to observe a household that in 2006 uses bank A to manage its payment of utilities and in 2008 uses bank B - i.e., has switched from bank A to bank B - to take out a mortgage in addition to (or instead of) its payment of utilities. Complementing this household-level information with bank-level information from BankScope enables us to relate the households' decision to switch their bank to the features of the household-bank relationship, controlling for household, bank and background characteristics.

We find robust evidence that the household's bank switching is strongly associated with the household-bank relationship features in terms of exclusivity (using a single bank), intensity (number of services used), and scope (bank services used). By looking at the dynamics of bank services a household uses over time, we find that both taking out and paying off a mortgage strongly increase the likelihood that a household switches a bank. Besides, several household characteristics which are traditionally identified as being associated with personal financial decisions - household size, marital status, education and financial literacy - matter for propensity to switch, whereas no role for the overall economic condition of the household is found. Finally, switching is found to be associated with specialization and market listing status of the bank, being less frequent among the households that are clients of the unlisted banks and cooperative banks. Background also matters, as the households living in provinces with more competitive bank markets are on average more likely to switch.

The rest of the paper is organized as follows. Next Section reviews the literature. Section 3 formalizes the hypotheses under analysis and the estimation strategy for their empirical test. Section 4 describes the datasets, the variables used, and provides the descriptive statistics. Section 5 presents the empirical findings and Section 6 discusses their robustness. Finally, Section 7 concludes. 


\section{Literature Review}

Our study lies at the intersection of two main streams of literature, namely banking and household finance.

Well-established literature on bank-firm relationships covers, among other topics, the importance of deposit relationships in traditional lending (Hodgman, 1961; Kane and Malkiel, 1965; and Santikian, 2014), relationship duration (Ongena and Smith, 1998 and 2001), number of bank relationships (Ongena and Smith, 2000; Farinha and Santos, 2002; Detragiache et al., 2000), the uniqueness of bank-firm relationship (Fama, 1985; James, 1987; Lummer and McConnell, 1989), the dynamics of consumer relationship in bank loan market (Sharpe, 1990), the importance of competition in credit markets (Petersen and Rajan, 1995), and firm's decision to switch bank (Gopalan et al. 2011; Degryse et al., 2011). Our investigation draws from this bank-firm relationship literature and adapts the framework to a household-bank relationship.

Besides, there is an increasing body of (positive) household finance literature (see Campbell, 2006 for an excellent review) that analyses how the households actually take financial decisions. Bulk of this literature focuses on the asset side of household's portfolio ${ }^{1}$ and relates it to the households' demographic and socio-economic characteristics. The decisions investigated cover consumption and saving (see e. g. Browning and Lusardi, 1996 and references therein), payment and borrowing, (see Cox and Jappelli, 1990 and 1993; Crook, 2001; Guiso et al., 2014), various types of insurance (Lin and Grace, 2007; Goldman and Maestas, 2013), and especially portfolio choices, concerning both financial (Guiso et al., 2002; Guiso and Sodini, 2012) and real assets (Flavin and Yamashita, 2002; Cocco, 2004; Battu et al., 2008; Brunetti and Torricelli, 2015). Remarkably, very few contributions in this literature have to date investigated the household-bank relationship and in particular the households' decision to change their bank. The exception is the literature on market discipline and bank runs, which focuses on clients' concern over bank's (potential) distress as a determinant of deposit ${ }^{1}$ As Zinman (2014) puts it: “... household debt is a neglected topic within the relatively neglected sub-field
of household finance”. 
interest rates, proportion of uninsured deposits, and deposit withdrawals (see e. g. Diamond and Dybvig, 1983; Iyer and Puri, 2012; Iyer et al., 2013; Demirguc-Kunt and Huizinga, 2004; Goldberg and Hudgins, 2002). Yet, in the literature on market discipline and bank runs the main motivation for the household to leave the bank is the belief that the bank might fail, and thus is the same across all households. By contrast, in this analysis we investigate the households' decision to leave their bank focusing on motives such as the household's needs and preferences rather than their concern over the bank's potential distress.

The contributions more close in spirit to our study are Kiser (2002), Brown and Hoffmann (2013) and Brown et al. (2013). Kiser (2002) empirically investigates the covariates of switching costs and decision to switch banks using a sample of 1,500 US households drawn from the 1999 Michigan Surveys of Consumers. She looks at the household socio-economic observables and self-reported reasons for remaining with the first-ever bank, finding a positive and significant role for income, age and especially homeownership, which may thus induce a "lock-in" effect and guarantee a long-term bank relationship. Brown and Hoffmann (2013) and Brown et al. (2013) rely on a telephone-based survey conducted in 2011 by GfK that samples around 1,500 Swiss households. In the former paper, the authors focus on 470 mortgage holders with multiple bank relationships to compare the mortgage and non-mortgage relations for the same household. They find that the mortgage relations are used within a broader scope of services, are held with the banks geographically closer to the household, and are more recently established compared to the non-mortgage relations. They also document a role of financial literacy, as more literate borrowers are less likely to hold a mortgage with a local bank. Brown et al. (2013) focus on the role of the switching costs and deposit insurance coverage in mitigating the risk of deposit withdrawals from a large, distressed commercial bank in the financial crisis period (2008-2009). They find that the household-level switching costs lower the propensity to withdraw the deposits from a distressed bank, whereas no effect is found for the deposit insurance coverage. 


\section{Hypotheses and Estimation Strategy}

In this section we present our testable hypotheses and the estimation strategy used in the empirical analysis.

Based on the switching cost theory, the households are expected to be less likely to switch if they face higher switching costs and/or have stronger ties to their main bank. Hence, to the extent that the multiplicity of bank relationships indicates weaker bank ties, we propose our fist hypothesis to be tested:

Hypothesis 1: The households having an exclusive relationship with their main bank, i.e., using only one bank, are less likely to switch.

Next, in the existing literature, a well-recognized proxy for the costs of switching is the number of bank services used (see e.g. Brown et al., 2013), also capturing the intensity of the relationship. As a matter of fact, each bank service adds up to the total switching costs, and the higher the number of services, the more difficult is for the household to precisely assess the total cost of switching. Furthermore, multiple bank services used give rise to the economies of scope, thus further discouraging switching. Based on these arguments, we formalize our next hypothesis:

Hypothesis 2: Household's propensity to switch is decreasing in the number of services it uses with the bank.

Finally, we argue that the household-bank relationship evolves over time due to

the change in the household's needs for the bank services. Since different banks may have a comparative advantage in different bank services, switching should be a function of the change in the bank services the household uses. Hence, our third hypothesis is:

Hypothesis 3: The change in bank services a household uses is an important driver of switching. 
In order to test our hypotheses and investigate the determinants of bank switching, we estimate the following probit model specification:

$$
\operatorname{Pr}\left(S_{i t}=1\right)=\Phi\left(\alpha+\mathbf{R}_{i t-1} \beta+\mathbf{H}_{i t-1} \gamma+\mathbf{B}_{i t-1} \delta+\mathbf{X}_{i t-1} \theta\right)
$$

where $S_{i t}\left(S_{\text {witch }}\right)$ is a binary variable taking value 1 if the household $i$ changes its (main) bank between $t-1$ and $t$, and 0 otherwise. Matrix $\mathbf{R}$ contains the main variables of interest, namely household-bank relationship characteristics in terms of exclusivity, intensity, and scope, as described in detail in Section 4.2. Matrices $\mathbf{H}$ and B include the households' demographic and socio-economic characteristics, and bank's characteristics, respectively. Finally, matrix $\mathbf{X}$ includes background controls. This specification allows us to disentangle the effects of household-bank relationship characteristics from the potentially confounding factors, such as household and bank features, as well as characteristics of the environment, which may all be associated with the household's propensity to switch a bank.

Importantly, all regressors are lagged one period. This choice is driven by a twofold advantage. First, it assures the model predetermination. Using the regressors from $t$ would be correct if and only if we knew that the switch from one bank to another occurred exactly in $t$. Yet, the exact timing of switching is unknown, where our dependent variable $S$ witch captures whether a bank switching occurred at some point in time between $t-1$ and $t$. Thus, the regressors from $t$ would introduce the risk of modelling the decision as a function of observables from a future point in time with respect to the decision itself. Second, this specification enables us to pinpoint the characteristics of the discarded bank that are positively associated with switching, thereby providing more ready-to-use suggestions for the banks aiming to strengthen their ties to the households. 
Since the probit model is nonlinear, we report the average marginal effects. ${ }^{2}$ The model is estimated by maximum likelihood, using robust standard errors clustered at the household level. ${ }^{3}$

\section{Data}

\subsection{Dataset}

The Bank of Italy Survey on Household Income and Wealth (SHIW) is a biannual survey which interviews in each wave a population-representative sample of around 8,000 Italian households. Half of the interviewed households are panel households. ${ }^{4}$ The survey encompasses plenty of information ranging from the basic demographic to various economic variables, including detailed information on household-bank relationship(s). Using the bank identifier enables us the following. First, we can observe which bank(s) each household uses in each wave, and, if multiple, which among those is the "main bank". Second, following the households over time, we are able to timely trace which households change their main bank, and, thus, to construct our dependent variable, Switch. Finally, we are able to match the household-level information to detailed bank-level information for the household's main bank. This additional information is obtained from BankScope (BS), which provides extensive information from bank balance sheets and income statements on a yearly basis, as well as the information on bank history, specialization and market listing status.

\footnotetext{
2 The marginal effects are computed as the (sample weighted) average of the marginal change in each household's probability to switch when each of the explanatory variables changes from 0 to 1 , if dichotomous, or by a marginal amount, if continuous. Our results are almost identical when we use a linear probability model (results available upon request).

${ }^{3}$ Following Petersen (2009), we check the robustness of our results to alternative clustering of the standard errors. Our main findings are largely unchanged with either clustering by time only or by household and time jointly.

${ }_{4}^{4}$ The statistical unit in the SHIW is the household, defined as a group of cohabiting people who, regardless of their relationships, satisfy their needs by pooling all or part of their incomes. For more information on the SHIW sampling and interviewing methodologies, see Bank of Italy (2012).

${ }^{5}$ See next subsection for the exact wording of the SHIW questionnaire.
} 
Our final dataset, spanning the 2006-2012 period, provides a rich set of information on the characteristics of the household and its relationship with the bank, complemented with the information on the bank features. Finally, we add data from Bank of Italy to define bank market concentration at the province level, so as to carry out one of the first attempts in the literature to provide a comprehensive picture of the household-bank relationship.

\subsection{Variable definitions}

This section describes the variables included in the empirical estimation of model (1).

The core information on household-bank relationship relies on the following three questions from the SHIW. The first concerns which bank(s) the household uses (Which among these [listed] banks do you use?'), and the second which among those is its main bank ("Which of these [circled] banks do you use most often?'). The third question relevant for our research focuses on the bank services used with the main bank: "Apart from your account, what other financial [listed] products/services of your main bank do you use?". The households may indicate one or more among the following: (i) payments of utilities, rent or other expenses; (ii) mortgage; (iii) consumer credit and personal loans; (iv) securities custody, administration and management; (v) insurance; and (vi) other (as reference category).

By means of this information, we construct our dependent variable, $S$ witch, which is defined in $t$ as a binary variable taking value 1 if household $i$ changes its main bank between wave $t-1$ and $t$, and 0 otherwise. ${ }^{6}$

\footnotetext{
${ }^{6}$ In doing so, due to the data limitation we could not control for local branch closures, but we fully took into account the restructuring and associated name changes at the national level. This seems particularly important given that during our sample period the Italian banking market underwent a strong consolidation process. If not properly taken into account these developments might undermine the correct construction of our dependent variable, since the banks that have changed names between two consecutive SHIW waves would have all households counted as "switchers" between wave $t-1$ and $t$. To correct for this, we did not consider as switching if a household uses a bank involved in a merger or an acquisition with the household's previous bank.
} 
Since a household may use multiple banks, switching the main bank may capture what we refer to as "bank shuffling". This is the case when the previous main bank becomes a secondary bank, or the previous secondary bank starts to be used as the main bank - i.e., the bank is used in both periods, but what changes is its reported relative frequency of use. Thus, we construct two alternative dependent variables to be used as a robustness check: Switch Drop is equal to 1 if a household changes its main bank dropping its previous bank (i.e., it does not become its secondary bank), and 0 otherwise, whereas Switch New is equal to 1 if a household switches to a bank with which it did not have any previous relationship (i.e., it does not switch to its secondary bank), and 0 otherwise.

Based on the same questions we also build the main variables of interest included in Matrix R, namely: (i) Exclusivity, a dummy taking value 1 if the household has relationship with one bank only, and 0 otherwise; (ii) Intensity (Nr. Total services), a categorical variable counting the number of bank services used by the household; and (iii) Scope of the relationship, capturing the actual nature of the household-bank relationship, via the bank services used distinguished by type. ${ }^{7}$ Namely, we include dummies for using Payments (payment of utilities, rent or other expenses); Insurance; Mortgage; Consumer credit; Portfolio management and Other services (besides the ones listed above). Exploiting the panel dimension of our dataset, we also observe the change in the bank services used with the main bank over time, thus capturing the change in the scope of a household-bank relationship. Specifically, for each bank service, we construct two dummy variables. The first dummy (Add [Specific service) takes value of 1 when the household does not use that service in $t-1$ but uses it in $t$, whereas the second dummy (Drop [Specific service) takes value of 1 when the household uses that service in $t-1$ but no longer uses it in $t$. This specification enables us to relate the household's decision to switch its main bank to a change in the bank services that the household requires.

\footnotetext{
${ }^{7}$ We refer to the services used with the main bank, as we do not have information on the services used with the secondary bank(s), if any.
} 
In line with the literature on household finance, matrix $\mathbf{H}$ includes standard demographic and socio-economic controls. Namely, we control for household size, as well as age, gender, marital status, education, financial literacy and risk aversion of the household head. ${ }^{8}$ Age is controlled for both in linear and quadratic terms, and gender and marital status by means of two dummies for being Male and Married, respectively. Education is controlled for with two dummies for the highest education level achieved, being secondary school or college (Medium education) and graduate or post-graduate level (High education), respectively. The questions included in the SHIW financial literacy test vary slightly from wave to wave, thus we focus on the two questions common to all the waves in our sample: one tests the comprehension of the different types of mortgage, whereas the other one of the real interest rates. On mortgages, the respondent is asked to indicate the type of mortgage (fixed rate, adjustable rate, or adjustable rate with fixed instalments) involving a fixed (in advance) number and amount of instalments to repay the debt. On real interest rates, the respondent is asked to indicate the amount of goods he/she can buy (the same, less, or more) at the end of the year if he/she leaves 1,000 euro in a bank account, for a year, at an annual interest rate of $1 \%$ in nominal terms, when annual inflation is $2 \%$. Accordingly, to control for household head's financial sophistication, we generate two dummies: one for providing the correct answer to only one question out of two (Intermediate financial literacy), and one for answering both questions correctly (Good financial literacy). The survey also provides a self-reported measure of Risk aversion, as the household head is asked to indicate the preferred investment profile among four types, ranging from 1 (high risk, high returns) to 4 (no risk, low returns). Our model specification includes a dummy taking value 1 if the preferred investment profile is the fourth (Risk-averse). The mobility of the household is controlled for by means of two dummies: one for having changed municipality of residence between $t-1$ and $t$ (Moved), and one for owning the residential house (Homeowner). Finally, the overall economic condition of the household is captured by Disposable income and Net wealth, both in quintiles. We also control for the household head's main professional occupation, including dummies for being

\footnotetext{
8 The head of the household in the SHIW is defined as the person in charge of taking the economic and
} financial choices of the household. 
Employee or Self-employed, thereby setting Not Employed (looking for a job, retired, students, housewives, etc.) as the reference category.

We also include a rich set of bank-level controls, gathered in matrix B. Specifically, we control for bank specialization, size, performance, market listing status, and recent involvement in a merger or an acquisition. Bank specialization is controlled for by means of two dummies for the bank being Cooperative or Saving, with Commercial banks being the reference category. Bank size is captured by the bank total assets (Size), whereas we also control for the bank profitability (Return on Assets - ROA) and leverage (Equity over Total asset). We also include a dummy for bank being Listed on the stock market and a dummy for $M \& A$ involvement that takes value of 1 if the bank was involved in $M \& A$ process between $t-1$ and $t$, and 0 otherwise.

Finally, in matrix $\mathbf{X}$ we include various background controls: macro-region (NorthEast, Centre, and South, with North-West as reference category) and time dummies, as well as a proxy for Bank market concentration, measured by the Herfindal index of the ATM points in the province of residence, ranging between 0 (perfect competition) and 1 (monopoly). 9

A detailed definition of all the variables used in the analysis is reported in the Appendix.

\subsection{Descriptive statistics}

The estimation sample covers the 2006-2012 period and consists of an unbalanced panel of 3,121 unique households, for a total of 5,057 household-level observations. ${ }^{10}$

\footnotetext{
${ }^{9}$ We also consider alternative measures of bank market concentration, namely: the Herfindal index for the number of branches (as opposed to ATM) in the province of residence, and the market share of the Top 3 banks by both ATM points and the number of branches (justified by the structure of the Italian bank market, in which almost 50\% of the households are clients of one of these 3 banks). The results (available upon request) obtained using these measures are largely unchanged.

${ }_{10}$ We exclude the households with the household head aged over 91 or below 19, as well as the households which possess neither financial nor real assets, or that report negative total consumption. We also drop the households who use a post office (around 15\% of the initial sample) or who report using a bank for which we do not have information in Bankscope.
} 
Table 1 reports descriptive statistics on the estimation sample. More than one out of five households in our sample changes its main bank ( $S_{\text {witch }}$ ). This ratio is multifold higher than a natural run-off rate of stable deposits which is 5\% in BIS guidelines (BIS, 2013). These descriptive statistics are almost identical to $S$ witch New and $S$ witch Drop, which indicates that "bank shuffling" is not prevalent, i.e., the households who change their main bank close their accounts and switch to a bank that they haven't used before. This is a striking result if we think of a well-documented phenomenon of inertia that characterizes household choices (see, e. g., Haliassos and Bertaut, 1995).

As for the household-bank relationship, almost $80 \%$ of the households have only one bank (Exclusivity) and the median household uses only one service in addition to their bank account (Nr. Total services). Changes in the services used are the most frequent for payments (5.5\% of the households in the sample add this service and $11.5 \%$ drop it), mortgages (5.9\% add it, and 5.6\% drop it), and portfolio management $(7.2 \%$ add, and $7.5 \%$ leave it).

The median household counts 2 household members, and the median household head is male, married, 54 years old and has completed a secondary school or college (Medium Education). As for the financial literacy, 32.5\% of respondents answered correctly one of the questions testing financial sophistication (Intermediate Financial Literacy), whereas 57.6\% answered both questions correctly (Good Financial Literacy). $42.4 \%$ of the households in our sample are Risk-averse. $41.2 \%$ of the household heads are Employee, $17 \%$ are Self-employed, while the rest are not employed.

The household's median annual disposable income is slightly more than $36,000 €$ and net wealth of around 229,000€. When it comes to the homeownership, around $75.8 \%$ of the households in our estimation sample own their residential home, whereas only $2 \%$ of the households moved from one municipality to another between two waves, suggesting that the mobility of the households in our sample is extremely low. Majority of the households $(83.6 \%)$ use a commercial bank as their main bank, $7 \%$ of the households use a saving bank, whereas $9.4 \%$ use a cooperative bank. The Bank market 
concentration proxied by the Herfindal index has an average of 0.136 on a scale from 0 (perfect competition) to 1 (monopoly).

\section{[Table 1 about here]}

Our sample includes 85 unique banks, 53 of which are commercial, 17 saving, and 15 cooperative banks. These banks are quite representative of the Italian banking industry, since as an example the commercial banks in our sample account for $97 \%$ of the total assets in the market (these shares are $52 \%$, and $43 \%$ for cooperative and saving banks, respectively).

The descriptive statistics for the bank-year observations are reported in Table 2 . Around $26 \%$ of the banks are listed. In terms of total assets, which we use as a proxy for size, the median bank has 11.84 billion euros. Notably, the median size of the cooperative banks is quite similar to those of the commercial ones and very much aligned to the overall average bank size, indicating that bank size is not necessarily associated to the bank specialization. We also report measures of the bank profitability and its funding structure, Equity/Total assets and Return on Assets (ROA) respectively, in order to disentangle the role of the bank's specialization for household's decision to switch its bank.

\section{[Table 2 about here]}

\section{Results}

Table 3 reports the estimation output of the first empirical counterpart of equation (1), in which the scope of the household-bank relationship is captured by the types of the bank services used by the household.

Consistently with the Hypothesis 1, having a relationship exclusively with one bank (Exclusivity) reduces the probability of switching. The effect is remarkable, as it almost reaches 9 percentage points. The effect of the number of services (Nr. Total services) goes in the same direction, thus supporting our Hypothesis 2: for each 
additional service used at the main bank, the household is almost $4 \%$ less likely to switch (see Column (1), Table 3). This result is consistent with the existing literature on switching costs (Brown et al., 2013).

In order to further investigate the latter finding, Column (2) in Table 3 provides a service-type break-down. The results show that the effect is mainly driven by Payments, Consumer credit, and portfolio management (Portfolio mgmt.), suggesting that these are the services which make the households more likely to stick to their bank. On the other hand, Mortgage and Insurance seem to form a weaker tie of the households to their banks. This heterogeneity of "stickiness" across various banks services is related to the variation in the switching costs that each service entails. Changing the bank used for payments purposes requires to inform all third parties associated with the service of the changed account number, whereas changing the portfolio management provider often implies untimely liquidation of the assets. The consumer credit is of lower debt burden and usually shorter maturity than a mortgage, thus the potential benefits of migrating a consumer credit to another bank are typically smaller, whereas the opposite is true for a mortgage loan. Changing insurance provider rarely entails costs for a household.

As for the bank's characteristics, Table 3 shows that neither having undergone a merger \& acquisition $(M \& A)$ process nor bank's performance (measured by $R O A$ and Equity/Total assets) play a role in the households' decision to leave the bank. On the other hand, the bank specialization is important. The estimates in Table 3 show that the cooperative banks are considerably less likely (around 10\%) to be discarded with respect to the commercial banks, whereas this is not true for the saving banks. Since we are controlling for bank's size and performance (the "hard" characteristics of a bank), the cooperative dummy captures a "soft" differentiation with respect to the commercial banks, which is primarily the difference in the value a bank attaches to its clients. Finally, the households are more prone to leave a listed bank, which may be ascribed to a more profit-oriented management of these banks. 
For the household controls, Table 3 shows that the probability of changing a bank slightly increases with Household size, whereas it is not associated with Age. The estimated association of the marital status goes in the expected direction: the households with a Married household head are less prone to change bank, which may result from the intra-household bargaining process, since for a couple to switch the two partners need to converge on the decision. ${ }^{11}$ An interesting result is that whereas the education has a positive gradient, a higher level of financial literacy is strongly and negatively associated with the bank switching. This finding suggests that the households with better financial comprehension are more able to choose the bank that better fits their needs in the first place, thus being less likely to change the bank in the future..$^{12}$ Based on our evidence, gender, working status and Risk averse do not play a determinant role for switching, and, interestingly not even income and wealth are associated with this decision. Additionally, both proxies for mobility - namely, being homeowner and having moved - seem to be irrelevant. This might well stem from the peculiarity of the Italian market, where the homeownership is quite high and changing the municipality of residence is very rare. To sum up, the household characteristics that shape the bank-switching decision are household size, marital status, education and financial literacy, rather than the mobility or the overall economic condition of the household.

Finally, the Bank market concentration has a negative sign, indicating that the households living in the provinces with a more competitive bank market have on average a higher probability to switch their banks. The time dummies, not shown for reasons of space, capture a decreasing trend in the probability to change a bank.

\section{[Table 3 about here]}

\footnotetext{
11 This interpretation stems from our starting point being the collective household model, in which the final decision of the household is the result of bargaining among all household members, as opposed to the unitary model, in which the breadwinner only takes all decisions. More on this issue e. g. in Bertocchi et al. (2014) and references therein.

${ }^{12}$ As a robustness check, we also estimate a specification in which financial literacy is modelled by three dummies: one for having answered correctly to the question on interest rates, one for having answered correctly to the question on mortgages and the third one for having answered correctly both questions. Our main results remain unchanged even under this specification, available upon request.
} 
In order to empirically test Hypothesis 3, we take into account the dynamics of the household-bank relationship via a set of dummies (Add and Drop) capturing the changes in a specific service used by the household. The results are reported in Table 4.

The evidence referring to the Exclusivity and to the Intensity are confirmed. Yet, new insights can be obtained on the service-driven switching. We find that the households opening a mortgage are $14.2 \%$ (Add mortgage) more likely to switch a bank. Similarly, closing a mortgage (Drop mortgage) also increases the probability of switching by $14 \%$. We find evidence supporting our Hypothesis 3 only with reference to long-term credit services. According to this evidence, in our sample the households' choice of a bank is strongly driven by the offered mortgage terms, but the chosen bank faces a challenge to retain the household after the mortgage has been paid off. This is not surprising considering that among all bank services, the mortgages are those for which the households are more able to assess the total cost, given by the interest rate, and, thus, the advantages of switching a bank. One might argue that the same holds for the consumer credit. Yet, the mortgages are associated with the purchase of a house, which is typically one of the most important investment decisions in the households' life-cycle, therefore entailing a higher level of due diligence that the households exercise.

\section{[Table 4 about here]}

To sum up, consistently with our testable hypotheses, the household decision to change its main bank seems to be strongly discouraged by the strength of the tie to the bank, as captured by the household using no other banks, by the costs of switching and to be mainly driven by bank services such as payments, consumer credit and portfolio management. Furthermore, taking out and paying off long-term credit are both found to be the strong determinants of the household's decision to switch its bank.

\section{Robustness}

The results presented in the previous section are robust to alternative specifications of both the dependent variable and of several controls. 


\subsection{Dependent variable}

Our dependent variable captures household's decision to change its main bank. We thus define our baseline dependent variable $S$ witch as being 1 if the household changes its main bank between waves $t-1$ and $t$. While definition of switching is straightforward for the households using only one bank and switching to another single bank relationship, for the households using multiple banks our measure of switching may capture what we refer to as "bank shuffling". These concerns are mitigated by the peculiarity of our sample, in which the majority of households use one bank only. However, to address this issue explicitly, we test the robustness of our results to more restrictive measures of switching, namely $S_{w i t c h} N e w$ and $S$ witch Drop, as defined in Section 4.2. The results are reported in Tables 5 to 8 and are qualitatively similar to those reported in Tables 3 and 4.

\section{[Table 5 to Table 8 about here]}

\subsection{Control variables}

In the specifications reported in Table 9 and Table 10 we use two alternative measures of Exclusivity to capture household's loyalty to its main bank, namely the number of banks used by the household (Nr. Banks), and a dummy taking value 1 if the household has been using its main bank for 10 years or more (Long-lasting relationship). In both tables, the former shows a positive marginal effect suggesting that for each additional bank used, a household is $6 \%$ more likely to change its main bank. Similarly in Table 10, the households who have been using their main bank since a long ago are $11 \%$ less likely to replace it with another bank.

[Table 9 and Table 10 about here] 


\section{Conclusion}

This paper empirically investigates the household's decision to change its main bank, a timely issue considering the increasing attention devoted to it by both the practitioners and the policy makers.

To this end, we rely on a dataset which is unique on several grounds. First, it observes the households and their bank(s) over time, providing ample information about the bank services used. This not only means that the households' decision to switch or stay is timely observed, rather than inferred based on the retrospective questions or the questions on intention to switch, but also that it can be related to the bank services used. Second, the dataset relies on a survey which is representative of the entire population. Third, it refers to the 2006-2012 period and to the Italian market, which particularly lends itself to this analysis since more than one out of five households do change their main bank. Finally, it is highly representative of the Italian bank market, thus enabling us to gauge the differences in switching vulnerability of different types of banks.

We find that the households are more reluctant to switch if they have an exclusive, long-lasting relationship with their bank, and/or use the bank more intensively, consistently with our first testable hypothesis. Specifically, the households having an exclusive relationship with the bank (or having been using the bank for longer than 10 years) are $11 \%$ less likely to switch. In line with our second hypothesis, for each additional service used, the probability of switching a bank reduces by around 4\%, thereby confirming the role of switching costs as discussed in the literature.

Finally, the scope of the relationship also matters since we document the heterogeneity of "stickiness" across various bank services, with Payments, Consumer credit, and portfolio management (Portfolio mgmt.) creating a stronger tie of the household to its bank. The mortgages are found to be a strong motivation for the household's decision to switch its bank, both when taking it out and having paid it off. Thus, we find evidence supporting our Hypothesis 3 only with respect to long term credit. These results suggest that the households' choice of a bank is strongly driven by 
the offered mortgage terms, but also that a chosen bank faces a challenge in retaining the households after the mortgage has been paid off.

We also find that the household size, marital status, education and financial literacy are associated with the decision to change bank, whereas mobility and the overall economic condition of the household are not.

Some of the characteristics of the discarded bank also matter, with the cooperative banks being significantly less likely to be abandoned. This result frames into the recently increasing attention devoted to the cooperative banks from academics, politicians and the public, who have wondered whether their specific characteristics have provided them with a safer shelter against the propagation of the global financial crisis (Hesse and Cihák, 2007).

The evidence that the cooperative banks are significantly less likely to be discarded may also serve as a recommendation to the policy makers. So far, Basel III liquidity requirements strongly discriminate between "stable" and "unstable" customer deposits. More specifically, the regulators assume that the customer deposits which are embedded in a well-established relationship are less subject to the withdrawal risk, thereby shaping the liquidity requirements based on the intensity of the relationship. According to our evidence, we can add that the liquidity requirements should evaluate the stability of the relationship not only based on its intensity but also based on the bank's specialization. 


\section{References}

Bank for International Settlements, 2013, Basel III: The liquidity coverage ratio and liquidity risk monitoring tools. Basel committee on banking supervision, BIS

Bank of Italy, 2012, Supplements to the statistical bulletin, Sample Surveys, Household Income and Wealth in 2010.

Battu, H., A. Ma and E. Phimister, 2008, Housing tenure, job mobility and unemployment in the UK, in The Economic Journal, Vol. 118(527), pages 311-328

Bertocchi, G., M. Brunetti and C. Torricelli, 2014, Who holds the purse strings within the household? The determinants of intra-family decision making, in Journal of Economic Behaviour and Organization, Vol. 101(5), pages 65-86

Brown, M. and M. Hoffmann, 2013, Mortgage relationships, Working Papers on Finance Nr. $2013 / 10$

Brown, M., B. Guin and S. Morkoetter, 2013, Switching costs, deposit insurance and deposit withdrawals from distressed banks, Working Papers on Finance $\mathrm{Nr}$. 2013/19

Browning, M. and A. Lusardi, 1996, Household saving: Micro theories and micro facts, in Journal of Economic Literature, Vol. 34(4), pages 1797-1855

Brunetti, M. and C. Torricelli, 2015, Second homes: households' life dream or (wrong) investment?, CeFin Working Papers Nr. 52

Campbell, J. Y., 2006, Household finance, in Journal of Finance, Vol. 61(4), pages 15531604

Cocco, J. F., 2004, Portfolio choice in the presence of housing, in Review of Financial Studies, Vol. 18(2), pages 535-567

Cox, D. and T. Jappelli, 1990, Credit rationing and private transfers: Evidence from survey data, in Review of Economics and Statistics, Vol. 72(3), pages 445-454

Cox, D. and T. Jappelli, 1993, The effect of borrowing constraints on consumer liabilities, in Journal of Money, Credit and Banking, Vol. 25(2), pages 197-213

Crook, J., 2001, The demand for household debt in the USA: Evidence from the 1995 survey of consumer finance, in Applied Financial Economics, Vol. 11(1), pages 8391 
De Bonis, R., Pozzolo, A.F. and Stacchini, M. (2012). The Italian banking system: facts and interpretations, Economics \& Statistics Discussion Paper, 068/12 Università del Molise

Degryse, H., N. Masschelein and J. Mitchell, 2011, Staying, dropping, or switching: The impacts of bank mergers on small firms, in Review of Financial Studies, Vol. 24(4), pages $1102-1140$

Demirguc-Kunt, A. and H. Huizinga, 2004, Market discipline and deposit insurance, in Journal of Monetary Economics, Vol. 51(2), pages 375-399

Detragiache, E., P. Garella and L. Guiso, 2000, Multiple versus single banking relationships: Theory and evidence, in Journal of Finance, Vol. 55(3), pages 11331161

Diamond, D. W. and P. Dybvig, 1983, Bank runs, deposit insurance, and liquidity, in Journal of Political Economy, Vol. 91(3), pages 401-419

Ernst and Young, 2012, Global consumer banking survey 2012

Fama, E., 1985, What's different about banks?, in Journal of Monetary Economics, Vol. 15(1), pages 29-39

Farinha, L. A. and J. Santos (2002), Switching from single to multiple bank lending relationships: Determinants and implications, in Journal of Financial Intermediation, Vol. 11(2), pages 124-151

Flavin, M. and T. Yamashita, 2002, Owner-occupied housing and the composition of the household portfolio over the life cycle, in American Economic Review, Vol. 92(1), pages $345-362$

Goldberg, L. G. and S. C. Hudgins, 2002, Depositor discipline and changing strategies for regulating thrift institutions, in Journal of Financial Economics, Vol. 63(2), pages $263-274$

Goldman, D. and N. Maestas, 2013, Medical expenditure risk and household portfolio choice, in Journal of Applied Econometrics, Vol. 28(4), pages 527-550

Gopalan, R., G. Udell and V. Yerramilli, 2011, Why do Firms form new banking relationships?, in Journal of Financial and Quantitative Analysis, Vol. 46(5), pages $1335-1365$ 
Guiso, L., G. Foà, L. Gambacorta and P. Mistrulli, 2014, The supply side of household finance, mimeo

Guiso, L. and P. Sodini, 2012, Household finance. An emerging field, in Handbook of the Economics of Finance, G. Constantinides, M. Harris and R. Stulz, Editors, pages 1397-1531, North Holland

Guiso, L., M. Haliassos and T. Jappelli, 2002, Household portfolios, MIT Press

Haliassos, M. and C. Bertaut, 1995, Why do so few hold stocks?, in Economic Journal, Vol. 105(432), pages 1110-1129

Hesse, H. and M.Cihák (2007), Cooperative banks and financial stability, International Monetary Fund Working Paper $07 / 02$

Hodgman, D. R., 1961, The deposit relationship and commercial bank investment behaviour, in Review of Economics and Statistics, Vol. 43(3), pages 257-268

Iyer, R. and M. Puri, 2012, Understanding bank runs: The importance of depositor bank relationships and networks, in American Economic Review, Vol. 102(4), pages 1414-1445

Iyer, R., M. Puri and N. Ryan, 2013, Do depositors monitor banks?, NBER Working Paper 19050

James, C., 1987, Some evidence on the uniqueness of bank loans, in Journal of Financial Economics, Vol. 19(2), pages 217-235

Kane, E. J. and B. G. Malkiel, 1965, Bank portfolio allocation, deposit variability, and the availability doctrine, in Quarterly Journal of Economics, Vol. 79(1), pages 257261

Kiser, E., 2002, Switching behavior and switching costs in household deposits, in Review of Industrial Organization, Vol. 20(4), pages 349-365

Lin, Y. and M. F. Grace, 2007, Household life cycle protection: Life insurance holdings, financial vulnerably and portfolio implications, in Journal of Risk and Insurance, Vol. 74(1), pages 141-173

Lummer, S. L. and J. McConnell, 1989, Further evidence on the bank lending process and the capital-market response to bank loan agreements, in Journal of Financial Economics, Vol. 25(1), pages 99-122 
Ongena, S. and D. Smith, 1998, Quality and duration of banking relationships, in Open Access publications from Tilburg University

Ongena, S. and D. Smith, 2000, What determines the number of bank relationships? Crosscountry evidence, in Journal of Financial Intermediation, Vol. 9(1), pages 2656

Ongena, S. and D. Smith, 2001, The duration of bank relationships, in Journal of Financial Economics, Vol. 61(3), pages 449-475

Petersen, M., 2009, Estimating standard errors in finance panel data sets: Comparing approaches, in Review of Financial Studies, Vol. 22(1), pages 435-480

Petersen, M. and R. Rajan, 1995, The effect of credit market competition on lending relationships, in Quarterly Journal of Economics, Vol. 110(2), pages 407-443

Santikian, L., 2014, The ties that bind: Bank relationships and small business lending, in Journal of Financial Intermediation Vol. 23(2), pages 177-213

Sharpe, S. A., 1990, Asymmetric information, bank lending, and implicit contracts: A stylized model of customer relationships, in Journal of Finance, Vol. 45(4), pages 1069-1087

Zinman, J., 2014, Household debt: Facts, puzzles, theories, and policies, NBER Economic Research Working Paper Series Nr. 20496 
Tables

Table 1: Descriptive statistics on the estimation sample

\begin{tabular}{|c|c|c|c|c|c|c|}
\hline Dependent variables & Obs & Mean & Median & Min & Max & St.Dev. \\
\hline Switch & 5,057 & 0.230 & 0 & 0 & 1 & 0.421 \\
\hline Switch New & 5,057 & 0.219 & 0 & 0 & 1 & 0.414 \\
\hline Switch Drop & 5,057 & 0.216 & 0 & 0 & 1 & 0.411 \\
\hline \multicolumn{7}{|l|}{ Control variables } \\
\hline \multicolumn{7}{|c|}{ R: Household-bank relationship characteristics } \\
\hline Exclusivity & 5,057 & 0.795 & 1 & 0 & 1 & 0.404 \\
\hline Nr. Banks & 5,057 & 1.238 & 1 & 1 & 5 & 0.506 \\
\hline Long-lasting relationship & 4,152 & 0.655 & 1 & 0 & 1 & 0.475 \\
\hline Nr. Total services & 5,057 & 1.371 & 1 & 0 & 5 & 0.757 \\
\hline Payments & 5,057 & 0.900 & 1 & 0 & 1 & 0.301 \\
\hline Insurance & 5,057 & 0.038 & 0 & 0 & 1 & 0.192 \\
\hline Mortgage & 5,057 & 0.151 & 0 & 0 & 1 & 0.358 \\
\hline Consumer credit & 5,057 & 0.041 & 0 & 0 & 1 & 0.199 \\
\hline Portfolio mgmt. & 5,057 & 0.196 & 0 & 0 & 1 & 0.397 \\
\hline Other services & 5,057 & 0.045 & 0 & 0 & 1 & 0.208 \\
\hline Add payments & 5,057 & 0.055 & 0 & 0 & 1 & 0.228 \\
\hline Add insurance & 5,057 & 0.022 & 0 & 0 & 1 & 0.145 \\
\hline Add mortgage & 5,057 & 0.059 & 0 & 0 & 1 & 0.235 \\
\hline Add consumer credit & 5,057 & 0.045 & 0 & 0 & 1 & 0.207 \\
\hline Add portfolio mgmt. & 5,057 & 0.072 & 0 & 0 & 1 & 0.258 \\
\hline Add other services & 5,057 & 0.048 & 0 & 0 & 1 & 0.213 \\
\hline Drop payments & 5,057 & 0.115 & 0 & 0 & 1 & 0.319 \\
\hline Drop insurance & 5,057 & 0.023 & 0 & 0 & 1 & 0.149 \\
\hline Drop mortgage & 5,057 & 0.056 & 0 & 0 & 1 & 0.229 \\
\hline Drop consumer credit & 5,057 & 0.025 & 0 & 0 & 1 & 0.157 \\
\hline Drop portfolio mgmt. & 5,057 & 0.075 & 0 & 0 & 1 & 0.264 \\
\hline Drop other services & 5,057 & 0.032 & 0 & 0 & 1 & 0.175 \\
\hline
\end{tabular}


Table 1: Descriptive statistics on the estimation sample (ctd.)

\begin{tabular}{|c|c|c|c|c|c|c|}
\hline & Obs & Mean & Median & Min & $\operatorname{Max}$ & St.Dev. \\
\hline \multicolumn{7}{|c|}{ H: Household characteristics } \\
\hline Household size & 5,057 & 2.632 & 2 & 1 & 8 & 1.241 \\
\hline Age & 5,057 & 54.326 & 54 & 20 & 90 & 14.326 \\
\hline Male & 5,057 & 0.666 & 1 & 0 & 1 & 0.472 \\
\hline Married & 5,057 & 0.691 & 1 & 0 & 1 & 0.462 \\
\hline Medium education & 5,057 & 0.685 & 1 & 0 & 1 & 0.465 \\
\hline High education & 5,057 & 0.143 & 0 & 0 & 1 & 0.350 \\
\hline Intermediate financial literacy & 5,057 & 0.325 & 0 & 0 & 1 & 0.468 \\
\hline Good financial literacy & 5,057 & 0.576 & 1 & 0 & 1 & 0.494 \\
\hline Risk-averse & 5,057 & 0.424 & 0 & 0 & 1 & 0.494 \\
\hline Moved & 5,057 & 0.020 & 0 & 0 & 1 & 0.138 \\
\hline Homeowner & 5,057 & 0.758 & 1 & 0 & 1 & 0.428 \\
\hline Employee & 5,057 & 0.412 & 0 & 0 & 1 & 0.492 \\
\hline Self-employed & 5,057 & 0.170 & 0 & 0 & 1 & 0.376 \\
\hline Income $(€ 1,000)$ & 5,057 & 43.041 & 36.25254 & 0 & 427.948 & 28.409 \\
\hline Net wealth $(€ 1,000)$ & 5,057 & 357.223 & 229.6137 & -875.424 & $30,933.84$ & 747.310 \\
\hline \multicolumn{7}{|c|}{ B: Bank characteristics } \\
\hline Commercial & 5,057 & 0.836 & 1 & 0 & 1 & 0.370 \\
\hline Saving & 5,057 & 0.070 & 0 & 0 & 1 & 0.255 \\
\hline Cooperative & 5,057 & 0.094 & 0 & 0 & 1 & 0.292 \\
\hline Size (in logs) & 5,057 & 11.046 & 11.09189 & 7.923757 & 13.94831 & 1.416 \\
\hline ROA & 5,057 & 0.666 & 0.78 & -1.4 & 2.36 & 0.464 \\
\hline Equity/Total assets & 5,057 & 7.067 & 6.88 & 2.35 & 25.21 & 2.845 \\
\hline Listed & 5,057 & 0.411 & 0 & 0 & 1 & 0.492 \\
\hline M\&A & 5,057 & 0.126 & 0 & 0 & 1 & 0.331 \\
\hline \multicolumn{7}{|c|}{$X:$ Background controls } \\
\hline North-Est & 5,057 & 0.115 & 0 & 0 & 1 & 0.319 \\
\hline North-West & 5,057 & 0.318 & 0 & 0 & 1 & 0.466 \\
\hline Centre & 5,057 & 0.322 & 0 & 0 & 1 & 0.467 \\
\hline South & 5,057 & 0.245 & 0 & 0 & 1 & 0.430 \\
\hline $\begin{array}{l}\text { Bank market concentration } \\
\text { (Herfindal index) }\end{array}$ & 5,057 & 0.136 & 0.120 & 0.053 & 0.427 & 0.059 \\
\hline
\end{tabular}

Note: all statistics are computed using sample weights. 
Table 2: Descriptive statistics at the bank level

\begin{tabular}{lrrrrrr}
\hline Variable & N & \multicolumn{1}{c}{ Mean } & Median & \multicolumn{1}{c}{ Min } & Max & St.Dev. \\
\hline Commercial & 238 & 0.61 & 1 & 0 & 1 & 0.49 \\
Saving & 238 & 0.21 & 0 & 0 & 1 & 0.41 \\
Coop & 238 & 0.18 & 0 & 0 & 1 & 0.39 \\
Listed & 238 & 0.26 & 0 & 0 & 1 & 0.44 \\
\hline Total assets (billions of euro) & 238 & 50.76 & 11.84 & 2.39 & $1,142.03$ & 153.19 \\
$\quad$-Commercial & 146 & 71.2 & 14.92 & 2.76 & $1,142.03$ & 192.15 \\
$\quad$-Saving & 49 & 11.29 & 5.67 & 2.39 & 50.8 & 11.75 \\
$\quad$-Cooperative & 43 & 26.32 & 11.89 & 2.81 & 135.79 & 30.18 \\
\hline Return on Assets (ROA) & 238 & 0.41 & 0.47 & -6.7 & 2.36 & 0.77 \\
$\quad$-Commercial & 146 & 0.42 & 0.52 & -6.7 & 2.36 & 0.91 \\
-Saving & 49 & 0.34 & 0.40 & -1 & 1.43 & 0.55 \\
-Cooperative & 43 & 0.45 & 0.46 & -1.17 & 1.07 & 0.40 \\
\hline Equity/Total assets & 238 & 7.85 & 7.48 & 1.44 & 25.21 & 3.09 \\
-Commercial & 146 & 7.63 & 7.00 & 1.44 & 25.21 & 3.54 \\
-Saving & 49 & 7.47 & 7.20 & 3.76 & 11.93 & 1.61 \\
$\quad$-Cooperative & 43 & 9.05 & 8.62 & 5.18 & 17.32 & 2.40 \\
\hline
\end{tabular}


Table 3: Marginal effects on the probability to switch, main specification.

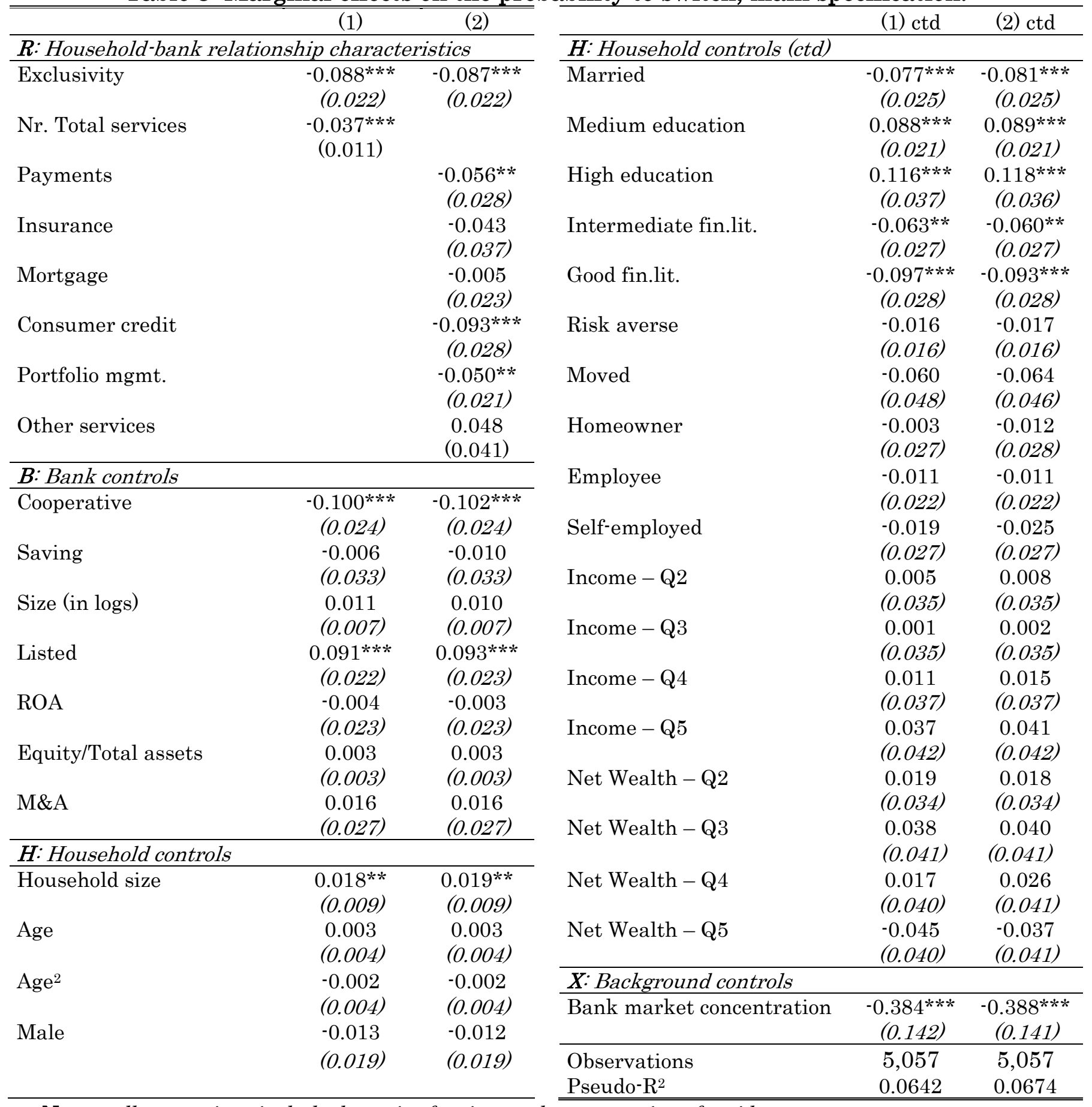

Notes: all regressions include dummies for time and macro-region of residence.

* significant at 10\%; ** significant at 5\%; *** significant at $1 \%$. 
Table 4: Marginal effects on the probability to switch, change services specification

\begin{tabular}{|c|c|c|c|}
\hline & $(1)$ & & (1) ctd \\
\hline $\boldsymbol{R}$ : Household-bank & & \multicolumn{2}{|l|}{ H: Household controls } \\
\hline Exclusivity & $\begin{array}{c}-0.083 * * * \\
(0.022)\end{array}$ & Household size & $\begin{array}{r}0.018^{* *} \\
(0.009)\end{array}$ \\
\hline Nr. Total services & $\begin{array}{c}-0.049^{* * * *} \\
(0.016)\end{array}$ & Age & $\begin{array}{l}0.002 \\
(0.004)\end{array}$ \\
\hline Add payments & $\begin{array}{l}0.054 \\
(0.038)\end{array}$ & $\mathrm{Age}^{2}$ & $\begin{array}{l}-0.001 \\
(0.004)\end{array}$ \\
\hline Drop payments & $\begin{array}{l}-0.001 \\
(0.026)\end{array}$ & Male & $\begin{array}{l}-0.016 \\
(0.019)\end{array}$ \\
\hline Add insurance & $\begin{array}{l}-0.031 \\
(0.049)\end{array}$ & Married & $\begin{array}{c}-0.081^{* * *} \\
(0.025)\end{array}$ \\
\hline Drop insurance & $\begin{array}{l}0.023 \\
(0.055)\end{array}$ & Medium education & $\begin{array}{c}0.089 * * * \\
(0.021)\end{array}$ \\
\hline Add mortgage & $\begin{array}{c}0.142^{* * *} \\
(0.040)\end{array}$ & High education & $\begin{array}{c}0.116^{* * * *} \\
(0.036)\end{array}$ \\
\hline Drop mortgage & $\begin{array}{c}0.140 * * * \\
(0.042)\end{array}$ & Intermediate fin.lit. & $\begin{array}{c}-0.054^{* *} \\
(0.026)\end{array}$ \\
\hline Add consumer credit & $\begin{array}{l}-0.021 \\
(0.035)\end{array}$ & Good fin.lit. & $\begin{array}{c}-0.088^{* * *} \\
(0.028)\end{array}$ \\
\hline Drop consumer credit & $\begin{array}{l}-0.047 \\
(0.045)\end{array}$ & Risk averse & $\begin{array}{l}-0.017 \\
(0.016)\end{array}$ \\
\hline Add portfolio mgmt. & $\begin{array}{l}-0.002 \\
(0.029)\end{array}$ & Moved & $\begin{array}{l}-0.066 \\
(0.047)\end{array}$ \\
\hline Drop portfolio mgmt. & $\begin{array}{l}0.041 \\
(0.032)\end{array}$ & Homeowner & $\begin{array}{l}-0.013 \\
(0.028)\end{array}$ \\
\hline Add other & $\begin{array}{c}-0.039 \\
(0.031)\end{array}$ & Employee & $\begin{array}{l}-0.016 \\
(0.022)\end{array}$ \\
\hline Drop other & $\begin{array}{l}0.093^{*} \\
(0.053)\end{array}$ & Self-employed & $\begin{array}{l}-0.032 \\
(0.027)\end{array}$ \\
\hline B: Bank controls & & Income - Q2 & 0.014 \\
\hline Cooperative & $\begin{array}{c}-0.106^{* * * *} \\
(0.024)\end{array}$ & Income - Q3 & $\begin{array}{c}(0.036) \\
0.009\end{array}$ \\
\hline Saving & $\begin{array}{l}-0.006 \\
(0.033)\end{array}$ & Income - Q4 & $\begin{array}{c}(0.036) \\
0.018\end{array}$ \\
\hline Size (in logs) & $\begin{array}{l}0.010 \\
(0.007)\end{array}$ & Income - Q5 & $\begin{array}{l}(0.038) \\
0.046\end{array}$ \\
\hline ROA & $\begin{array}{c}0.095^{* * *} \\
(0.023)\end{array}$ & Net Wealth - Q2 & $\begin{array}{l}(0.042) \\
0.017\end{array}$ \\
\hline Equity/Total assets & $\begin{array}{l}-0.003 \\
(0.023)\end{array}$ & Net Wealth - Q3 & $\begin{array}{l}(0.034) \\
0.036\end{array}$ \\
\hline Listed & $\begin{array}{l}0.003 \\
(0.003)\end{array}$ & Net Wealth - Q4 & $\begin{array}{l}(0.040) \\
0.022\end{array}$ \\
\hline M\&A & $\begin{array}{l}0.011 \\
(0.026)\end{array}$ & Net Wealth - Q5 & $\begin{array}{l}(0.040) \\
-0.042 \\
(0.040)\end{array}$ \\
\hline & & X: Background controls & \\
\hline & & Bank market concentration. & $\begin{array}{c}-0.354^{* *} \\
(0.139)\end{array}$ \\
\hline & & $\begin{array}{l}\text { Observations } \\
\text { Pseudo-R }\end{array}$ & $\begin{array}{c}5,057 \\
0.0773 \\
\end{array}$ \\
\hline
\end{tabular}

Notes: all regressions include dummies for time and macro-region of residence.

* significant at $10 \% ; * *$ significant at 5\%; $* * *$ significant at $1 \%$. 
Table 5: Robustness: Switch New as dependent, main specification.

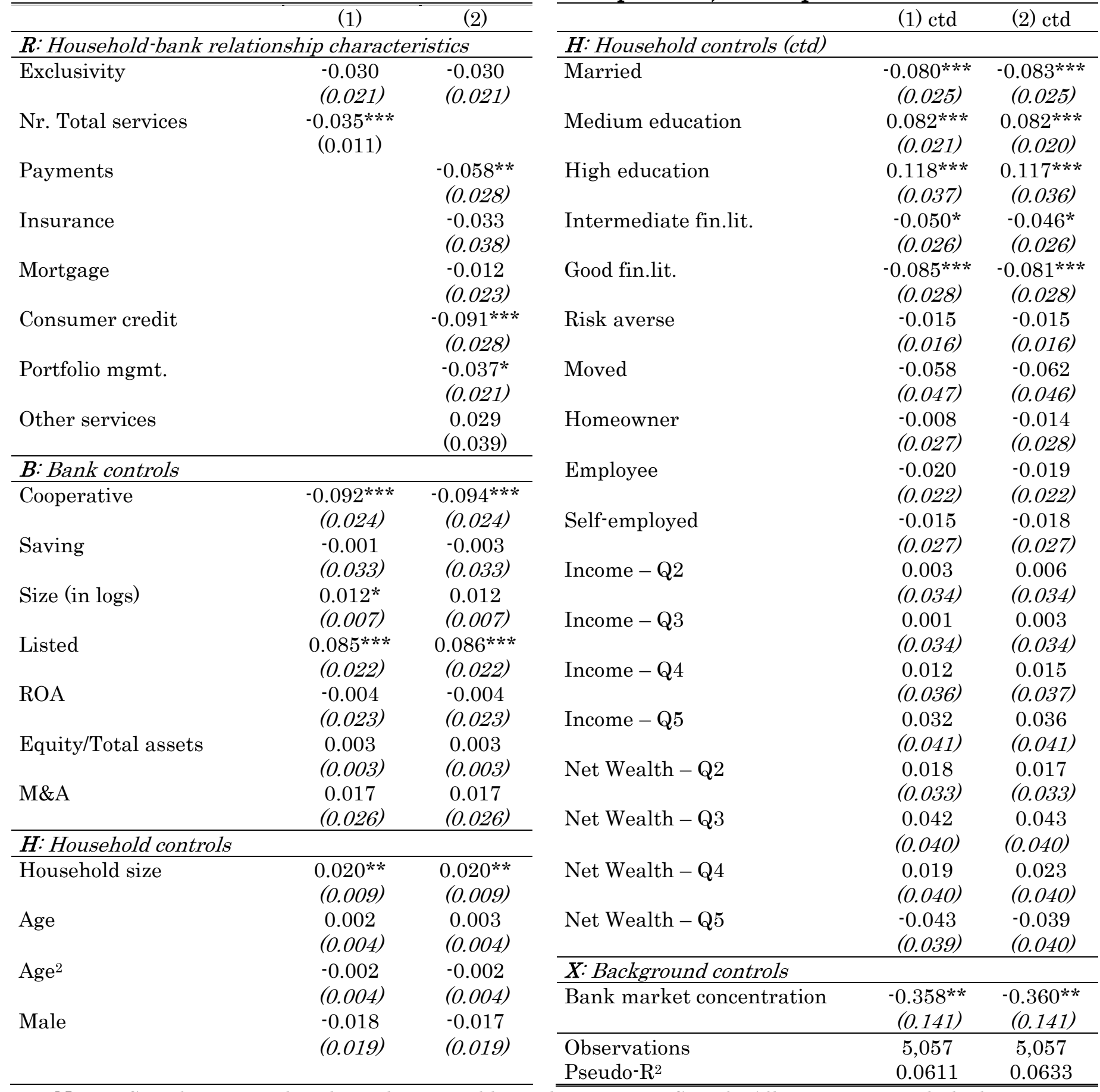

Notes: Switch New used as dependent variable in alternative to Switch. All regressions include dummies for time and macro-region of residence.

$*$ significant at $10 \% ; * *$ significant at $5 \% ; * * *$ significant at $1 \%$. 
Table 6: Robustness: Switch New as dependent, change services specification.

\begin{tabular}{|c|c|c|c|}
\hline & (1) & & (1) $\mathrm{ctd}$ \\
\hline \multicolumn{2}{|l|}{$R:$ Household-bank } & \multicolumn{2}{|l|}{ H: Household controls } \\
\hline Exclusivity & $\begin{array}{l}-0.027 \\
(0.021)\end{array}$ & Household size & $\begin{array}{r}0.019^{* *} \\
(0.008)\end{array}$ \\
\hline Nr. Total services & $\begin{array}{c}-0.043^{* * *} \\
(0.016)\end{array}$ & Age & $\begin{array}{l}0.002 \\
(0.004)\end{array}$ \\
\hline Add payments & $\begin{array}{l}0.061 \\
(0.038)\end{array}$ & $\mathrm{Age}^{2}$ & $\begin{array}{l}-0.002 \\
(0.004)\end{array}$ \\
\hline Drop payments & $\begin{array}{l}-0.011 \\
(0.026)\end{array}$ & Male & $\begin{array}{l}-0.020 \\
(0.019)\end{array}$ \\
\hline Add insurance & $\begin{array}{l}-0.030 \\
(0.049)\end{array}$ & Married & $\begin{array}{c}-0.083^{* * * *} \\
(0.025)\end{array}$ \\
\hline Drop insurance & $\begin{array}{l}0.029 \\
(0.056)\end{array}$ & Medium education & $\begin{array}{c}0.082^{* * *} \\
(0.020)\end{array}$ \\
\hline Add mortgage & $\begin{array}{c}0.131^{* * *} \\
(0.040)\end{array}$ & High education & $\begin{array}{c}0.115^{* * *} \\
(0.036)\end{array}$ \\
\hline Drop mortgage & $\begin{array}{c}0.119 * * * \\
(0.041)\end{array}$ & Intermediate fin.lit. & $\begin{array}{l}-0.041 \\
(0.026)\end{array}$ \\
\hline Add consumer credit & $\begin{array}{l}-0.024 \\
(0.034)\end{array}$ & Good fin.lit. & $\begin{array}{c}-0.077 * * * \\
(0.027)\end{array}$ \\
\hline Drop consumer credit & $\begin{array}{l}-0.042 \\
(0.045)\end{array}$ & Risk averse & $\begin{array}{l}-0.015 \\
(0.016)\end{array}$ \\
\hline Add portfolio mgmt. & $\begin{array}{l}0.005 \\
(0.030)\end{array}$ & Moved & $\begin{array}{l}-0.063 \\
(0.046)\end{array}$ \\
\hline Drop portfolio mgmt. & $\begin{array}{l}0.042 \\
(0.032)\end{array}$ & Homeowner & $\begin{array}{l}-0.017 \\
(0.027)\end{array}$ \\
\hline Add other & $\begin{array}{c}-0.036 \\
(0.031)\end{array}$ & Employee & $\begin{array}{l}-0.024 \\
(0.022)\end{array}$ \\
\hline Drop other & $\begin{array}{c}0.061 \\
(0.050)\end{array}$ & Self-employed & $\begin{array}{l}-0.025 \\
(0.026)\end{array}$ \\
\hline B: Bank controls & & Income - Q2 & 0.011 \\
\hline Cooperative & $\begin{array}{c}-0.097^{* * * *} \\
(0.024)\end{array}$ & Income - Q3 & $\begin{array}{l}(0.035) \\
0.007\end{array}$ \\
\hline Saving & $\begin{array}{l}0.001 \\
(0.033)\end{array}$ & Income-Q4 & $\begin{array}{c}(0.034) \\
0.017\end{array}$ \\
\hline Size (in logs) & $\begin{array}{l}0.011 \\
(0.007)\end{array}$ & Income - Q5 & $\begin{array}{c}(0.037) \\
0.039\end{array}$ \\
\hline ROA & $\begin{array}{c}0.089 * * * \\
(0.022)\end{array}$ & Net Wealth - Q2 & $\begin{array}{l}(0.041) \\
0.016\end{array}$ \\
\hline Equity/Total assets & $\begin{array}{l}-0.004 \\
(0.023)\end{array}$ & Net Wealth - Q3 & $\begin{array}{l}(0.033) \\
0.039\end{array}$ \\
\hline Listed & $\begin{array}{l}0.003 \\
(0.003)\end{array}$ & Net Wealth - Q4 & $\begin{array}{c}(0.040) \\
0.021\end{array}$ \\
\hline M\&A & $\begin{array}{l}0.012 \\
(0.026)\end{array}$ & Net Wealth - Q5 & $\begin{array}{l}(0.040) \\
-0.042 \\
(0.039) \\
\end{array}$ \\
\hline & & $X:$ Background controls & \\
\hline & & Bank market concentration & $\begin{array}{c}-0.332 * * \\
(0.139)\end{array}$ \\
\hline & & $\begin{array}{l}\text { Observations } \\
\text { Pseudo-R }\end{array}$ & $\begin{array}{c}5,057 \\
0.0722 \\
\end{array}$ \\
\hline
\end{tabular}

Notes: Switch New used as dependent variable in alternative to Switch. All regressions include dummies for time and macro-region of residence.

* significant at 10\%; ** significant at 5\%; *** significant at $1 \%$. 
Table 7: Robustness: Switch Drop as dependent, main specification.

\begin{tabular}{|c|c|c|c|c|c|}
\hline & (1) & $(2)$ & & (1) ctd & (2) $\mathrm{ctd}$ \\
\hline \multicolumn{3}{|c|}{$\boldsymbol{R}:$ Household-bank relationship characteristics } & \multicolumn{3}{|l|}{ H: Household controls (ctd) } \\
\hline Exclusivity & $\begin{array}{l}-0.033 \\
(0.021)\end{array}$ & $\begin{array}{l}-0.033 \\
(0.021)\end{array}$ & Married & $\begin{array}{c}-0.069^{* * * *} \\
(0.025)\end{array}$ & $\begin{array}{c}-0.073^{* * *} \\
(0.025)\end{array}$ \\
\hline Nr. Total services & $\begin{array}{c}-0.035^{* * *} \\
(0.011)\end{array}$ & & Medium education & $\begin{array}{c}0.080^{* * * *} \\
(0.021)\end{array}$ & $\begin{array}{c}0.080^{* * *} \\
(0.020)\end{array}$ \\
\hline Payments & & $\begin{array}{c}-0.056^{* *} \\
(0.028)\end{array}$ & High education & $\begin{array}{c}0.105^{* * * *} \\
(0.036)\end{array}$ & $\begin{array}{c}0.106 * * * \\
(0.036)\end{array}$ \\
\hline Insurance & & $\begin{array}{l}-0.029 \\
(0.039)\end{array}$ & Intermediate fin.lit. & $\begin{array}{c}-0.054^{* *} \\
(0.026)\end{array}$ & $\begin{array}{l}-0.050^{*} \\
(0.026)\end{array}$ \\
\hline Mortgage & & $\begin{array}{l}-0.009 \\
(0.023)\end{array}$ & Good fin.lit. & $\begin{array}{c}-0.091 * * * \\
(0.028)\end{array}$ & $\begin{array}{c}-0.087 * * * \\
(0.027)\end{array}$ \\
\hline Consumer credit & & $\begin{array}{c}-0.092^{* * * *} \\
(0.027)\end{array}$ & Risk averse & $\begin{array}{l}-0.013 \\
(0.016)\end{array}$ & $\begin{array}{l}-0.014 \\
(0.016)\end{array}$ \\
\hline Portfolio mgmt. & & $\begin{array}{c}-0.044^{* *} \\
(0.020)\end{array}$ & Moved & $\begin{array}{l}-0.054 \\
(0.047)\end{array}$ & $\begin{array}{l}-0.059 \\
(0.046)\end{array}$ \\
\hline Other services & & $\begin{array}{l}0.053 \\
(0.041)\end{array}$ & Homeowner & $\begin{array}{l}-0.005 \\
(0.027)\end{array}$ & $\begin{array}{l}-0.012 \\
(0.027)\end{array}$ \\
\hline B: Bank controls & & & Employee & 0.007 & 0.007 \\
\hline Cooperative & $\begin{array}{c}-0.098^{* * *} \\
(0.023)\end{array}$ & $\begin{array}{c}-0.100 * * * * \\
(0.023)\end{array}$ & Self-employed & $\begin{array}{l}(0.022) \\
-0.003\end{array}$ & $\begin{array}{l}(0.022) \\
-0.009\end{array}$ \\
\hline Saving & $\begin{array}{l}0.002 \\
(0.033)\end{array}$ & $\begin{array}{l}-0.002 \\
(0.033)\end{array}$ & Income - Q2 & $\begin{array}{l}(0.028) \\
-0.001\end{array}$ & $\begin{array}{l}(0.027) \\
0.002\end{array}$ \\
\hline Size (in logs) & $\begin{array}{l}0.014^{*} \\
(0.007)\end{array}$ & $\begin{array}{l}0.013^{*} \\
(0.007)\end{array}$ & Income - Q3 & $\begin{array}{l}(0.034) \\
-0.002\end{array}$ & $\begin{array}{l}(0.034) \\
0.000\end{array}$ \\
\hline Listed & $\begin{array}{c}0.074^{* * *} \\
(0.022)\end{array}$ & $\begin{array}{c}0.074 * * * \\
(0.022)\end{array}$ & Income - $\mathrm{Q} 4$ & $\begin{array}{l}(0.034) \\
0.003\end{array}$ & $\begin{array}{c}(0.034) \\
0.007\end{array}$ \\
\hline ROA & $\begin{array}{l}-0.008 \\
(0.023)\end{array}$ & $\begin{array}{l}-0.008 \\
(0.023)\end{array}$ & Income - Q5 & $\begin{array}{c}(0.036) \\
0.027\end{array}$ & $\begin{array}{c}(0.036) \\
0.031\end{array}$ \\
\hline Equity/Total assets & $\begin{array}{l}0.004 \\
(0.003)\end{array}$ & $\begin{array}{l}0.004 \\
(0.003)\end{array}$ & Net Wealth - Q2 & $\begin{array}{l}(0.041) \\
0.023\end{array}$ & $\begin{array}{c}(0.041) \\
0.022\end{array}$ \\
\hline M\&A & $\begin{array}{l}0.014 \\
(0.026)\end{array}$ & $\begin{array}{l}0.014 \\
(0.026)\end{array}$ & Net Wealth - Q3 & $\begin{array}{c}(0.034) \\
0.038\end{array}$ & $\begin{array}{c}(0.033) \\
0.039\end{array}$ \\
\hline H: Household controls & & & & $(0.040)$ & $(0.040)$ \\
\hline Household size & $\begin{array}{l}0.016^{*} \\
(0.009)\end{array}$ & $\begin{array}{l}0.016^{*} \\
(0.009)\end{array}$ & Net Wealth - Q4 & $\begin{array}{l}0.027 \\
(0.040)\end{array}$ & $\begin{array}{l}0.034 \\
(0.040)\end{array}$ \\
\hline Age & $\begin{array}{l}0.002 \\
(0.004)\end{array}$ & $\begin{array}{l}0.002 \\
(0.004)\end{array}$ & Net Wealth - Q5 & $\begin{array}{l}-0.040 \\
(0.039)\end{array}$ & $\begin{array}{l}-0.034 \\
(0.040)\end{array}$ \\
\hline $\mathrm{Age}^{2}$ & -0.001 & -0.001 & X: Background controls & & \\
\hline Male & $\begin{array}{l}(0.004) \\
-0.021\end{array}$ & $\begin{array}{l}(0.004) \\
-0.020\end{array}$ & Bank market concentration & $\begin{array}{c}-0.402^{* * *} \\
(0.140)\end{array}$ & $\begin{array}{c}-0.406^{* * *} \\
(0.140)\end{array}$ \\
\hline & $(0.019)$ & $(0.019)$ & $\begin{array}{l}\text { Observations } \\
\text { Pseudo-R }\end{array}$ & $\begin{array}{c}5,057 \\
0.0613 \\
\end{array}$ & $\begin{array}{c}5,057 \\
0.0646 \\
\end{array}$ \\
\hline
\end{tabular}

Notes: Switch Drop used as dependent variable in alternative to Switch. All regressions include dummies for time and macro-region of residence.

${ }^{*}$ significant at $10 \% ; * *$ significant at 5\%; *** significant at $1 \%$. 
Table 8: Robustness: Switch Drop as dependent, change services specification.

\begin{tabular}{|c|c|c|c|}
\hline & $(1)$ & & (1) ctd \\
\hline \multicolumn{2}{|l|}{$R$ : Household-bank } & \multicolumn{2}{|l|}{ H: Household controls } \\
\hline Exclusivity & $\begin{array}{l}-0.029 \\
(0.021)\end{array}$ & Household size & $\begin{array}{l}0.015^{*} \\
(0.008)\end{array}$ \\
\hline Nr. Total services & $\begin{array}{c}-0.050 * * * \\
(0.016)\end{array}$ & Age & $\begin{array}{l}0.002 \\
(0.004)\end{array}$ \\
\hline Add payments & $\begin{array}{l}0.048 \\
(0.037)\end{array}$ & $\mathrm{Age}^{2}$ & $\begin{array}{l}-0.001 \\
(0.004)\end{array}$ \\
\hline Drop payments & $\begin{array}{l}-0.007 \\
(0.026)\end{array}$ & Male & $\begin{array}{l}-0.024 \\
(0.018)\end{array}$ \\
\hline Add insurance & $\begin{array}{l}-0.022 \\
(0.049)\end{array}$ & Married & $\begin{array}{c}-0.072^{* * *} \\
(0.024)\end{array}$ \\
\hline Drop insurance & $\begin{array}{l}0.046 \\
(0.058)\end{array}$ & Medium education & $\begin{array}{c}0.080 * * * \\
(0.020)\end{array}$ \\
\hline Add mortgage & $\begin{array}{c}0.131^{* * * *} \\
(0.040)\end{array}$ & High education & $\begin{array}{c}0.104^{* * * *} \\
(0.036)\end{array}$ \\
\hline Drop mortgage & $\begin{array}{c}0.139 * * * \\
(0.042)\end{array}$ & Intermediate fin.lit. & $\begin{array}{l}-0.045^{*} \\
(0.026)\end{array}$ \\
\hline Add consumer credit & $\begin{array}{l}-0.016 \\
(0.034)\end{array}$ & Good fin.lit. & $\begin{array}{c}-0.082^{* * *} \\
(0.027)\end{array}$ \\
\hline Drop consumer credit & $\begin{array}{l}-0.036 \\
(0.045)\end{array}$ & Risk averse & $\begin{array}{l}-0.014 \\
(0.016)\end{array}$ \\
\hline Add portfolio mgmt. & $\begin{array}{l}-0.002 \\
(0.029)\end{array}$ & Moved & $\begin{array}{l}-0.061 \\
(0.046)\end{array}$ \\
\hline Drop portfolio mgmt. & $\begin{array}{l}0.046 \\
(0.032)\end{array}$ & Homeowner & $\begin{array}{l}-0.015 \\
(0.027)\end{array}$ \\
\hline Add other & $\begin{array}{l}-0.048 \\
(0.030)\end{array}$ & Employee & $\begin{array}{l}0.002 \\
(0.022)\end{array}$ \\
\hline Drop other & $\begin{array}{l}0.101^{*} \\
(0.054)\end{array}$ & Self-employed & $\begin{array}{l}-0.016 \\
(0.027)\end{array}$ \\
\hline B: Bank controls & & Income - Q2 & 0.007 \\
\hline Cooperative & $\begin{array}{c}-0.103^{* * *} \\
(0.023)\end{array}$ & Income - Q3 & $\begin{array}{l}(0.034) \\
0.006\end{array}$ \\
\hline Saving & $\begin{array}{l}0.002 \\
(0.033)\end{array}$ & Income - $\mathrm{Q} 4$ & $\begin{array}{l}(0.034) \\
0.010\end{array}$ \\
\hline Size (in logs) & $\begin{array}{l}0.013^{*} \\
(0.007)\end{array}$ & Income - Q5 & $\begin{array}{l}(0.036) \\
0.036\end{array}$ \\
\hline ROA & $\begin{array}{c}0.078^{* * *} \\
(0.022)\end{array}$ & Net Wealth - Q2 & $\begin{array}{l}(0.041) \\
0.021\end{array}$ \\
\hline Equity/Total assets & $\begin{array}{l}-0.008 \\
(0.023)\end{array}$ & Net Wealth - Q3 & $\begin{array}{l}(0.033) \\
0.035\end{array}$ \\
\hline Listed & $\begin{array}{l}0.004 \\
(0.003)\end{array}$ & Net Wealth - Q4 & $\begin{array}{l}(0.039) \\
0.031\end{array}$ \\
\hline M\&A & $\begin{array}{l}0.009 \\
(0.026)\end{array}$ & Net Wealth - Q5 & $\begin{array}{l}(0.040) \\
-0.038 \\
(0.039)\end{array}$ \\
\hline & & $X$ : Background controls & \\
\hline & & Bank market concentration & $\begin{array}{c}-0.371^{* * *} \\
(0.138)\end{array}$ \\
\hline & & $\begin{array}{l}\text { Observations } \\
\text { Pseudo-R }\end{array}$ & $\begin{array}{c}5,057 \\
0.0744\end{array}$ \\
\hline
\end{tabular}

Notes: Switch Drop used as dependent variable in alternative to $S_{w i t c h}$. All regressions include dummies for time and macro-region of residence.

* significant at $10 \%$; ** significant at 5\%; *** significant at $1 \%$. 
Table 9: Robustness: alternative measures for household loyalty, main specification

\begin{tabular}{|c|c|c|c|c|}
\hline & $(1)$ & $(2)$ & $(3)$ & $(4)$ \\
\hline \multicolumn{5}{|c|}{$R:$ Household-bank relationship characteristics } \\
\hline Nr. Banks & $\begin{array}{c}0.060^{* * *} \\
(0.015)\end{array}$ & $\begin{array}{c}0.060^{* * *} \\
(0.015)\end{array}$ & & \\
\hline Long-lasting relationship & & & $\begin{array}{c}-0.110^{* * * *} \\
(0.021)\end{array}$ & $\begin{array}{c}-0.108^{* * *} \\
(0.021)\end{array}$ \\
\hline Nr. Total services & $\begin{array}{c}-0.036^{* * *} \\
(0.011)\end{array}$ & & $\begin{array}{c}-0.030^{* *} \\
(0.012)\end{array}$ & \\
\hline Payments & & $\begin{array}{c}-0.054^{*} \\
(0.028)\end{array}$ & & $\begin{array}{l}-0.028 \\
(0.030)\end{array}$ \\
\hline Insurance & & $\begin{array}{l}-0.042 \\
(0.037)\end{array}$ & & $\begin{array}{l}-0.059 \\
(0.037)\end{array}$ \\
\hline Mortgage & & $\begin{array}{l}-0.003 \\
(0.023)\end{array}$ & & $\begin{array}{l}-0.013 \\
(0.025)\end{array}$ \\
\hline Consumer credit & & $\begin{array}{c}-0.093^{* * * *} \\
(0.029)\end{array}$ & & $\begin{array}{r}-0.078^{* *} \\
(0.035)\end{array}$ \\
\hline Portfolio mgmt. & & $\begin{array}{c}-0.051^{* *} \\
(0.021)\end{array}$ & & $\begin{array}{l}-0.035 \\
(0.023)\end{array}$ \\
\hline Other services & & $\begin{array}{c}0.049 \\
(0.041)\end{array}$ & & $\begin{array}{c}0.044 \\
(0.047) \\
\end{array}$ \\
\hline Observations & 5,057 & 5,057 & 4,152 & 4,152 \\
\hline Pseudo-R² & 0.0633 & 0.0666 & 0.0756 & 0.0776 \\
\hline
\end{tabular}

Note: Exclusivity is substituted with Nr. Banks in Columns (1) to (2), and with Long-lasting relationship in Columns (3) to (4). All regressions also include matrices $\boldsymbol{B}, \boldsymbol{H}$ and $\boldsymbol{X}$.

$*$ significant at $10 \% ; * *$ significant at $5 \% ; * * *$ significant at $1 \%$. 
Table 10: Robustness: alternative measures for household loyalty, change services specification.

\begin{tabular}{|c|c|c|}
\hline & (1) & $(2)$ \\
\hline \multicolumn{3}{|c|}{$\boldsymbol{R}:$ Household-bank relationship characteristics } \\
\hline Nr. Banks & $\begin{array}{c}0.057^{* * *} \\
(0.015)\end{array}$ & \\
\hline Long-lasting relationship & & $\begin{array}{c}-0.105^{* * *} \\
(0.021)\end{array}$ \\
\hline Nr. Total services & $\begin{array}{c}-0.048^{* * *} \\
(0.016)\end{array}$ & $\begin{array}{c}-0.044^{* *} \\
(0.017)\end{array}$ \\
\hline Add payments & $\begin{array}{l}0.052 \\
(0.038)\end{array}$ & $\begin{array}{l}0.052 \\
(0.042)\end{array}$ \\
\hline Drop payments & $\begin{array}{l}0.000 \\
(0.026)\end{array}$ & $\begin{array}{c}0.008 \\
(0.028)\end{array}$ \\
\hline Add insurance & $\begin{array}{l}-0.033 \\
(0.048)\end{array}$ & $\begin{array}{l}-0.051 \\
(0.049)\end{array}$ \\
\hline Drop insurance & $\begin{array}{l}0.025 \\
(0.055)\end{array}$ & $\begin{array}{c}0.006 \\
(0.053)\end{array}$ \\
\hline Add mortgage & $\begin{array}{c}0.142^{* * *} \\
(0.040)\end{array}$ & $\begin{array}{r}0.170 * * * \\
(0.046)\end{array}$ \\
\hline Drop mortgage & $\begin{array}{c}0.141^{* * *} \\
(0.042)\end{array}$ & $\begin{array}{r}0.156^{* * *} \\
(0.045)\end{array}$ \\
\hline Add consumer credit & $\begin{array}{l}-0.021 \\
(0.035)\end{array}$ & $\begin{array}{l}-0.010 \\
(0.038)\end{array}$ \\
\hline Drop consumer credit & $\begin{array}{l}-0.046 \\
(0.045)\end{array}$ & $\begin{array}{l}-0.019 \\
(0.052)\end{array}$ \\
\hline Add portfolio mgmt. & $\begin{array}{l}-0.002 \\
(0.030)\end{array}$ & $\begin{array}{c}0.018 \\
(0.035)\end{array}$ \\
\hline Drop portfolio mgmt. & $\begin{array}{l}0.041 \\
(0.032)\end{array}$ & $\begin{array}{l}0.065^{*} \\
(0.035)\end{array}$ \\
\hline Add other services & $\begin{array}{l}-0.042 \\
(0.031)\end{array}$ & $\begin{array}{l}-0.030 \\
(0.034)\end{array}$ \\
\hline Drop other services & $\begin{array}{l}0.095^{*} \\
(0.053)\end{array}$ & $\begin{array}{c}0.071 \\
(0.061) \\
\end{array}$ \\
\hline $\begin{array}{l}\text { Observations } \\
\text { Pseudo-R }{ }^{2}\end{array}$ & $\begin{array}{c}5,057 \\
0.0765\end{array}$ & $\begin{array}{c}4,152 \\
0.0920\end{array}$ \\
\hline
\end{tabular}

Note: Exclusivity is substituted with Nr. Banks in Column (1) and with Long-lasting relationship in Column (2). All regressions include matrices $\boldsymbol{B}, \boldsymbol{H}$ and $\boldsymbol{X}$.

* significant at $10 \% ; * *$ significant at 5\%;*** significant at $1 \%$. 
Switch

Switch New

Switch Drop
Binary variable taking value 1 if the household changes its main bank between $t-1$ and $t$, and 0 otherwise.

SHIW Binary variable taking value 1 if the household changes its main bank switching to a new one with which it did not have SHIW any previous relationship, and 0 otherwise.

Binary variable taking value 1 if the household changes its main bank without keeping it as a secondary bank, and 0 SHIW otherwise.

\section{Controls variables}

$\boldsymbol{R}$ : Household-bank relationship characteristics

Exclusivity Binary variable taking value 1 if the household has only one bank, and 0 otherwise.

SHIW Categorical variable counting the total number of bank services used by the household.

SHIW

Nr. Total services Binary variable taking value 1 if the household uses its main bank for the payment of utilities, rent and other expenses, and SHIW 0 otherwise.

Insurance Binary variable taking value 1 if the household uses its main bank for insurance services, and 0 otherwise.

SHIW Binary variable taking value 1 if the household uses its main bank for mortgage, and 0 otherwise.

SHIW

Mortgage

Consumer Credit Binary variable taking value 1 if the household uses its main bank for consumer credit or personal loans, and 0 otherwise.

SHIW

Portfolio mgmt. Binary variable taking value 1 if the household uses its main bank for securities custody, administration and management, SHIW and 0 otherwise.

Other services Binary variable taking value 1 if the household uses its main bank for other services besides those described above, and 0 SHIW otherwise.

Add [Specific service] Binary variable taking value 1 if the household does not use the specific service in $t-1$, but uses it in $t$, and 0 otherwise.

Drop [Specific service] Binary variable taking value 1 if a household uses a specific service in $t-1$, but does not use it in $t$, and 0 otherwise.

SHIW Variable counting the number of banks the household has relationship with (used as an alternative measure of SHIW household's loyalty to its main bank). 
Variable

Long-lasting

relationship
Description

Source
Binary variable taking value 1 if a household has been using its main bank for more than 10 years, and 0 otherwise (used as an alternative measure of household's loyalty to its main bank).

\section{H: Household characteristics}

Household size

Male

Age, Age $^{2}$

Married

Medium Education, High Education

Intermediate

Financial Literacy, Good Financial Literacy Categorical variable counting the number of household members.

Binary variable taking value 1 for male household head, 0 for female.

Integer variables representing the age of household head and its quadratic form.

Binary variable taking value 1 if the household head is married, and 0 otherwise.

Binary variables taking value 1 for the corresponding level of education: Medium education corresponds to having completed secondary school and/or college; High education corresponds to having obtained a graduated and/or post-graduate degree. Reference category is Low education, i.e., having completed only primary education or having no education at all.

Binary variables taking value 1 for the corresponding level of financial literacy: Intermediate financial literacy corresponds to having answered correctly only one question out of two; Good financial literacy corresponds to having answered correctly to both questions. Reference category is Low Financial Literacy, meaning having given no correct answer.

Risk averse Binary variable taking value 1 if risk aversion level is 4,0 otherwise. Risk-aversion is measured by a categorical variable representing the preferred risk profile of financial investments:

$1=$ High risk, high returns

$2=$ Reasonable risk, good returns

$3=$ Low risk, reasonable returns

$4=$ No risk, low returns

Moved

Binary variable taking value 1 if the household changed its residence from one municipality to another between $t-1$ and $t$, SHIW and 0 otherwise.

Homeowner Binary variable taking value 1 if the household owns his its primary residence, and 0 otherwise. 


\begin{tabular}{|c|c|c|}
\hline $\begin{array}{l}\text { Employee, Self- } \\
\text { employed }\end{array}$ & $\begin{array}{l}\text { Binary variables taking value } 1 \text { for household heads being in } \\
\text { the corresponding occupational status, } 0 \text { otherwise. Reference } \\
\text { category is non-employed. }\end{array}$ & SHIW \\
\hline $\begin{array}{l}\text { Income (Net Wealth) } \\
\text { quintiles }\end{array}$ & $\begin{array}{l}\text { Binary variables taking value } 1 \text { if household's yearly } \\
\text { disposable income (net wealth, defined as the sum of real and } \\
\text { financial assets net of liabilities) is within the relevant } \\
\text { distribution quintile, and } 0 \text { otherwise. }\end{array}$ & SHIW \\
\hline \multicolumn{3}{|c|}{ B: Bank characteristics } \\
\hline Size (in logs) & Bank's total assets. & $\mathrm{BS}$ \\
\hline $\begin{array}{l}\text { Commercial, } \\
\text { Cooperative, Saving }\end{array}$ & $\begin{array}{l}\text { Binary variables taking value } 1 \text { for the corresponding bank's } \\
\text { specialization. The reference category is Commercial bank. }\end{array}$ & $\mathrm{BS}$ \\
\hline Listed & $\begin{array}{l}\text { Binary variable taking value } 1 \text { if the bank is listed, and } 0 \\
\text { otherwise. }\end{array}$ & $\mathrm{BS}$ \\
\hline M\&A & $\begin{array}{l}\text { Boinary variable taking value } 1 \text { if the bank underwent a } \\
\text { process of Merge \& Acquisition between } t-1 \text { and } t \text {, and } 0 \\
\text { otherwise. }\end{array}$ & $\mathrm{BS}$ \\
\hline Equity/Total assets & $\begin{array}{l}\text { Variable representing the ratio between bank's equity and } \\
\text { total assets, in percentage points. }\end{array}$ & BS \\
\hline $\mathrm{ROA}$ & $\begin{array}{l}\text { Variable representing the return on asset, namely the ratio } \\
\text { between the bank's pre-tax profits and assets, in percentage } \\
\text { points. }\end{array}$ & $\mathrm{BS}$ \\
\hline \multicolumn{3}{|c|}{$X:$ Background characteristics } \\
\hline $\begin{array}{l}\text { Time dummies } \\
(2008,2010)\end{array}$ & $\begin{array}{l}\text { Dummy variables taking value } 1 \text { in the relevant year, and } 0 \\
\text { otherwise. The reference category is } 2006 \text {. }\end{array}$ & SHIW \\
\hline $\begin{array}{l}\text { Macro-region } \\
\text { dummies }\end{array}$ & $\begin{array}{l}\text { Dummy variables taking value } 1 \text { for the relevant macro-region } \\
\text { (North-West, Centre, South) of residence, and } 0 \text { otherwise. The } \\
\text { reference category is North-East. }\end{array}$ & SHIW \\
\hline $\begin{array}{l}\text { Bank market } \\
\text { concentration }\end{array}$ & $\begin{array}{l}\text { Normalized Herfindal index of banks' ATM points in the } \\
\text { province of household's residence, ranging between } 0 \text { (perfect } \\
\text { competition) and } 1 \text { (monopoly). }\end{array}$ & $\mathrm{BI}$ \\
\hline
\end{tabular}

Note: SHIW is Survey on Household Income and Wealth; BS is BankScope; BI is Bank of Italy. 